\title{
EDUKASI DIABETES, PEMERIKSAAN GULA DARAH DAN KOLESTEROL DI GEREJA KRISTEN PASUNDAN YERUEL CIBUBUR
}

\author{
Michael Recard Sihombing ${ }^{1}$, Theresia ${ }^{2}$, Riama Marlyn Sihombing ${ }^{3}$, Ineke Patrisia ${ }^{4}$ \\ ${ }^{1}$ Fakultas Ilmu Pendidikan Universitas Pelita Harapan \\ ${ }^{2}$ Fakultas Keperawatan dan Ilmu Kesehatan Universitas Pelita Harapan \\ ${ }^{3}$ Fakultas Keperawatan dan Ilmu Kesehatan Universitas Pelita Harapan \\ ${ }^{4}$ Fakultas Keperawatan dan Ilmu Kesehatan Universitas Pelita Harapan
}

michael.recard@uph.edu, theresia.fon@uph.edu,riama.sihombing@uph.edu, ineke.patrisia@uph.edu

\begin{abstract}
Abstrak
Diabetes Melitus (DM) merupakan penyakit yang dapat mengakibatkan terjadinya berbagai penyulit menahun dan juga biasa disebut the silent killer sehingga perlu dilakukan tindakan pencegahan yang efektif dan efisien. Tim PkM dari Fakultas Keperawatan dan Ilmu Kesehatan Universitas Pelita Harapan bekerja sama dengan Komisi Pelayanan Kesehatan Gereja Kristen Pasundan Yeruel Cibubur telah melakukan edukasi dan pemeriksaan pada tanggal 3 November 2018. Pada saat kegiatan ditemukan peserta berjenis kelamin perempuan $(66,67 \%)$ lebih banyak dibandingkan dengan peserta berjenis kelamin laki-laki (33,33\%), distribusi kelompok umur ditemukan jumlah yang terbanyak $(41,67 \%)$ peserta berusia antara 45 - 59 tahun. Berdasarkan hasil pemeriksaan kesehatan ditemukan kurang dari setengah $(40 \%)$ peserta memiliki tekanan darah prehipertensi, kurang dari setengah $(45 \%)$ mempunyai IMT normal, lebih dari setengah $(78,33 \%)$ kolesterol normal dan hanya sebagian kecil $(3,33 \%)$ ditemukan kadar gula darah sewaktu yang meningkat sedangkan lebih dari setengah $(66,67 \%)$ kadar asam urat dalam batas normal. Dari kegiatan edukasi diabetes dan pelatihan pengukuran tekanan darah menunjukkan adanya peningkatan nilai pre-test dan post test. Kegiatan pengabdian masyarakat berjalan dengan lancar dan terjalin kerjasama tim yang baik. Untuk kegiatan selanjutnya komisi kesehatan perlu melakukan pengukuran tekanan darah secara rutin kepada anggota jemaat khususnya penderita hipertensi agar jemaat terhindar dari komplikasi penyakit hipertensi.
\end{abstract}

Kata Kunci : Edukasi, pemeriksaan, pengukuran tekanan darah

\section{PENDAHULUAN}

Diabetes Melitus (DM) merupakan penyakit yang terjadi karena adanya peningkatan kadar gula darah dalam tubuh, biasa juga disebut dengan kencing manis atau penyakit gula. Peningkatan gula darah tersebut dikarenakan penurunan sekresi insulin yang progresif (American Diabetes Association, 2015).
Diabetes mellitus merupakan penyakit metabolic dimana penderita memiliki nilai gula darah tinggi karena masalah sekresi insulin. Diabetes mellitus dapat menyerang orang dari segala jenis usia, ras ataupun jenis kelamin (Gutter, 2018). Diabetes Mellitus (DM) merupakan penyakit gangguan metabolik menahun akibat pancreas tidak memproduksi cukup insulin atau tubuh tidak dapat 
menggunakan insulin secara efektif (Infodatin, 2014). Maka dapat disimpulkan bahwa penyakit diabetes mellitus merupakan penyakit metabolic menahun yang disebabkan ketidakmampuan pancreas dalam memproduksi insulin.

Diabetes mellitus merupakan salah satu factor predisposisi dari kelainan mikrovaskular seperti retinopati, nefropati dan neuropati, selain itu diabetes mellitus juga berhubungan degan risiko penyakit aterosklerosis (Boedisantoso, et.al, 2009).

IDF dalam Indodatin (2014) mendapatkan data bahwa sebanyak 382 juta orang yang hidup dengan diabetes mellitus di dunia spada tahun 2013. Diperkirakan jumlah tersebut akan meningkat hingga 592 juta orang pada tahun 2035. Riskesdas (2013) mendapatkan data diabetes mellitus di Indonesia pada tahun 2013 meningkat hingga dua kali lipat dibandingkan dengan tahun 2007. Data penderita diabetes mellitus di Indonesia sebesar 6,9\%, sebesar $29,9 \%$ toleransi glukosa terganggu (TGT), 36,6\% glukosa darah puasa (GDP) terganggu. Diabetes mellitus juga terjadi di penduduk pedesaan, dimana penduduk di pedesaan menderita diabetes mellitus hamper sama dengan penderita diabetes mellitus di perkotaan. Prevalensi diabetes melitus meningkat dari 1,1 persen (2007) menjadi 2,1 persen (2013) (Riskesdas, 2013). Riskesdas 2013 dalam infodatin (2014) mendapatkan data bahwa terdapat $0,6 \%$ penduduk usia 15 tahun keatas atau sekitar 1 juta orang sebenearnya merasakan gejala diabetes mellitus dalam sebulan terakhir, namun belum memastikan apakah mereka menderita diabetes atau tidak.

Diabetes mellitus terbagi atas beberapa jenis yaitu diabetes melitus tipe 1 (diabetes melitus tergantung insulin), diabetes melitus tipe 2 (diabetes melitus tidak tergantung insulin), diabetes melitus gestational dan diabetes melitus tipe lain (Pedoman Pengendalian diabetes melitus dan Penyakit Metabolik, 2008). Penyakit diabetes mellitus tipe 2 merupakan jenis diabetes yang paling banyak diderita. Hal ini disebabkan oleh penyakit diabetes mellitus tipe 2 tidak mendesak untuk memerlukan insulin dalam tubuhnya, karena untuk diabetes tipe 2 biasanya jumlah insulin normal bahkan berlebih, akan tetapi berkurangnya jumlah reseptor yang ada dipermukaan sel (Maulana, 2009).
Penyakit diabetes mellitus tipe 2 memiliki gejala yang khas, namun masih ada beberapa penderita yang tidak memperhatikan dan tidak menyadari bahwa mereka mengalami gejala diabetes. Gejala umum yang biasa dialami oleh penderita diabetes adalah para penderita biasnya akan lebih sering untuk buang air kecil (BAK), sering merasa haus, sering merasa lapar (meskipun mereka sedang ataupun sudah makan), kelelahan yang luar biasa, pandangan yang kabur, luka atau memar yang lambat sembuh, penurunan berat badan, kesemutan, nyeri atau mati rasa di tangan ataupun di kaki. Gejala yang ditimbulkan pada penyakit diabetes tipe 1 berbeda antara bayi, anak dan juga orang dewasa. Anak kecil yang sering buang air kecil, minum dalam jumlah yang besar, kehilangan berat badan dan menjadi lebih mudah untuk Lelah dan sakit merupakan gambaran dari seorang anak uyang mengalami diabetes tipe 1 yang baru saja muncul, sedangkan gejala yang ditimbulkan pada prang dewasa dengan penyakit diabetes mellitus tipe 2 hampir sama dengan gejala penyakit diabetes tipe 2 , hal ini yang bias membuat keliru orang dewasa, sehingga terkadang mereka memahaminya bahwa mereka terkena penyakit diabetes mellitus tipe 2 (American Diabetes Association, 2019). Meskipun ada banyak kesamaan antara diabetes tipe 1 dan diabetes tipe 2 , namun yang menjadi penyebab dari kedua penyakit tersebut berbeda. Perawatan untuk jenis diabetesnya pun juga berbeda untuk diabetes tipe 1 dan diabetes melitus tipe 2 .

Penyakit diabetes melitus jika tidak dikelola dengan baik akan dapat mengakibatkan terjadinya berbagai penyulit menahun, seperti penyakit serebrovaskular, penyakit jantung koroner, penyakit pembuluh darah tungkai, gangguan pada mata, ginjal dan syaraf. Penyandang diabetes melitus mempunyai risiko 2 kali lebih besar untuk mengalami penyakit jantung koroner dan penyakit pembuluh darah otak, 5 kali lebih mudah menderita ulkus/gangren, 7 kali lebih mudah mengidap gagal ginjal terminal, dan 25 kali lebih mudah mengalami kebutaan akibat kerusakan retina daripada pasien non diabetes. Usaha untuk menyembuhkan kembali menjadi normal sangat sulit jika sudah terjadi penyulit, karena kerusakan yang terjadi umumnya akan menetap. Usaha pencegahan diperlukan lebih dini untuk mengatasi penyulit tersebut dan diharapkan akan

$$
\text { Kesehatan }
$$


sangat bermanfaat untuk menghindari terjadinya berbagai hal yang tidak menguntungkan (Riskesdas, 2013)

Salah satu penyakit yang disebut dengan the silent killer merupakan penyakit diabetes mellitus. Hal ini disebabkan oleh banyaknya keluhan yang akan ditimbulkan oleh penyakit ini, sebab diabetes mellitus dapat mengenai semua organ yang ada di dalam tubuh. Ada beberapa penyakit lain yang dapat ditimbulkan oleh diabetes mellitus diantaranya adalah gangguan penglihatan mata, katarak, penyakit jantung, sakit ginjal, impotensi seksial, sulitnya luka untuk sembuh sehingga akan membuat luka membusuk/gangrene, infeksi paru-paru, gangguan pembuluh darah, stroke dan sebagainya. Tidak jarang penderita diabetes mellitus yang mengalami luka berat dan sudah membusuk serta sulit disembuhkan akan menjalani amputasi anggota tubuhnya (Depkes, 2005).

Begitu banyak dampak yang diberikan dari penyakit diabetes mellitus, termasuk terhadap kualitas sumber daya manusia dan juga peningkatan biaya kesehatan yang cukup besar, oleh karena itu sangat diperlukan program pengendalian diabetes mellitus tipe 2. Hal ini dapat dicegah dan ditunda bahkan dihilangkan dengan mengendalikan faktor risiko (Kemenkes, 2010). Faktor risiko diabetes tipe 2 terbagi atas dua, yaitu pertama adalah faktor risiko yang tidak dapat dirubah seperti jenis kelamin, umur dan faktor genetik. Faktor yang kedua adlaah faktor risiko yang dapat dirubah seperti kebiasaan merokok dan gaya hidup (Bustan, 2000).

Irawan (2010) dalam penelitiannya menyatakan bahwa demografi, faktor perilaku, gaya hidup serta keadaan klinis dan mental memiliki pengaruh terhadap kejadian diabetes mellitus tipe 2 . Riskesdas tahun 2007 dalam Irawan (2010) mendapatkan data bahwa prevalensi diabetes melitus sebesar $12,41 \%$ terjadi pada kelompok usia 45 tahun dan ini merupakan hasil tertinggi. Data ini juga menunjukan bahwa terdapat hubungan antara kejadian diabetes mellitus dengan faktor risiko yaitu jenis kelamin, status perkawinan, tingkat pendidikan, pekerjaan, aktivitas fisik, kebiasaan merokok, konsumsi alkohol, Indeks Masa Tubuh, lingkar pinggang, dan umur. Sebesar 22,6\% kasus diabetes melitus Tipe 2 di populasi dapat dicegah jika obesitas sentral diintervensi.
Tim Pengabdian kepada Masyarkat (PkM) dari Fakultas Keperawatan dan Ilmu Kesehatan Universitas Pelita Harapan bekerjasama dengan Komisi Pelayanan Kesehatan Gereja Kristen Pasundan Yeruel Cibubur pernah melakukan pemeriksaan darah pada hari Sabtu, 3 Juni 2017. Hasil screening menunjukkan bahwa sebagian besar peserta $(61,70 \%)$ berjenis kelamin perempuan, berusia di atas 45 tahun $(82,65)$, memiliki tekanan darah tinggi $(75,11 \%)$, overweight $(59,57 \%)$ dan kadar kolesterol meningkat $(53,19 \%)$.

\section{METODE}

Target peserta dalam kegiatan ini adalah jemaat Gereja Kristen Pasundan Yeruel Cibubur yang dewasa dan lansia yang berusia di atas 45 tahun berjumlah 77 orang. Kegiatan ini diselengarakan dua kali, kegiatan pertama diselenggarakan pada hari Sabtu 3 November 2019 pukul 08.00-11.00 WIB dalam bentuk screening atau pemeriksaan pemeriksaan tekanan darah, tinggi badan, berat badan, kebiasaan merokok, kolesterol, asam urat pada semua peserta. Kegiatan kedua dilakukan apda hari Sabtu, 3 November 2019 dalam bentuk edukasi diabetes kepada semua peserta di Gereja Kristen Pasundan Yeruel Cibubur.

Metode pelaksaanan dalam kegiatan ini adalah screening. Dalam kegiatan screening ini fasilitator melakukan wawancara dan juga pemeriksaan tekanan darah, tinggi badan, berat badan, kebiasaan merokok, kolesterol, asam urat pada semua peserta. Setelah semua itu dilakukan semua peserta mendapatkan informasi tentang hasil pemeriksaan yang dilakukan

Setelah dilakukan pemeriksaan para peserta diberikan seminar dan juga demonstrasi. Dalam kegiatan ini pemateri menyampaikan materi sesuai dengan topik yang telah ditentukan, yaitu edukasi tentang diabetes melitus. Peserta seminar menyimak informasi penyaji dari awal hingga akhir kegiatan seminar dan mengajukan tanggapan, sanggahan, usul, saran, dan pertanyaan yang relevan dengan masalah pembicaraan pada termin diskusi. Untuk mengevaluasi kegiatan ini, peserta diberikan prepost test tentang materi seminar dan hasil screening.

Evaluasi diberikan dalam bentuk kuesioner atau pertanyaan manfaat pelatihan dan gambaran 
pengetahuan baru yang didapatkan oleh peserta sebelum dan setelah diberikan edukasi kesehatan. Dalam rangka menjamin keberlanjutan program, Fakultas Keperawatan dan Ilmu Kesehatan Universitas Pelita Harapan akan melakukan kegiatan melakukan Training of Trainer (TOT) teknik pengukuran tekanan darah terhadap para pengurus Komisi Pelayanan Kesehatan Gereja Kristen Pasundan Yeruel Cibubur pada Sabtu, 3 November 2018 pukul 13.00 - 14.00 WIB. Hal ini dilakukan atas dasar kebutuhan pelatihan bagi pengurus komisi karena lebih dari $50 \%$ pengurus tidak memiliki latar belakang pendidikan di bidang kesehatan. Padahal pengurus Komisi Pelayanan Kesehatan Gereja Kristen Pasundan Yeruel Cibubur sering diminta oleh jemaat untuk mengukur tekanan darah setelah atau sebelum ibadah ketika jemaat merasakan keluhan. Dengan adanya pelatihan Training of Trainer (TOT) ini, diharapkan para pengurus memiliki bekal yang lebih baik untuk mendeteksi tanda tanda-tanda hipoglikemia atau hiperglikemia yang dimanifestasikan dengan penurunan atau peningkatan tekanan darah sehingga dapat mendeteksi lebih dini adanya peningkatan atau penurunan faktor risiko diabetes pada anggota jemaat.

\section{HASIL DAN PEMBAHASAN}

\section{Hasil Kegiatan Pemeriksaan dan Edukasi Diabetes}

Seluruh peserta kegiatan berjumlah 83 orang tetapi jumlah dokumentasi hasil pemeriksaan kesehatan adalah 60 orang dengan rentang usia $26-76$ tahun. Semua peserta tampak antusias mengikuti pemeriksaan kesehatan hingga selesai. Bahkan ada beberapa peserta yang datang lebih awal sebelum kegiatan dimulai. Dapat dilihat pada tabel distribusi peserta berdasarkan faktor risiko yang tidak dapat dimodifikasi.

Tabel 1. Distribusi peserta berdasarkan faktor risiko yang tidak dapat dimodifikasi

\begin{tabular}{lcc}
\hline \multicolumn{1}{c}{ Variabel } & Jumlah & Persentasi (\%) \\
\hline Jenis kelamin & & \\
Laki-laki & 20 & 33,33 \\
Perempuan & 40 & 66,67 \\
Umur & & \\
Very old (> 90 & 0 & 0
\end{tabular}

\begin{tabular}{lll}
$\begin{array}{l}\text { tahun }) \\
\text { Old }(75-90\end{array}$ & 2 & 3,33 \\
tahun) & & \\
$\begin{array}{l}\text { Elderly }(60- \\
71 \text { tahun })\end{array}$ & 22 & 36,67 \\
$\begin{array}{l}\text { Middle age } \\
(45-59 \text { tahun })\end{array}$ & 25 & 41,67 \\
$\begin{array}{l}\text { Adult }(<45 \\
\text { tahun })\end{array}$ & 11 & 18,33 \\
\hline \multicolumn{1}{c}{ Total } & 60 & 100 \\
\hline
\end{tabular}

Pada tabel 1 dapat dilihat bahwa peserta berjenis kelamin perempuan sebanyak 40 peserta $(66,67 \%)$ lebih banyak dibandingkan dengan peserta berjenis kelamin laki-laki sebanyak 20 peserta $(33,33 \%)$. Berdasarkan distribusi kelompok umur ditemukan jumlah yang terbanyak sebesar 25 peserta $(41,67 \%)$ dengan range usia antara $45-59$ tahun. Untuk usia kurang dari 45 tahun sebanyak 11 peserta (18,33\%). Usia 75-90 tahun sebanyak 2 peserta $(3,33 \%)$, usia $60-71$ tahun sebanyak 22 peserta $(36,67 \%)$.

Tabel 2. Distribusi peserta berdasarkan faktor risiko yang dapat dimodifikasi

\begin{tabular}{|c|c|c|}
\hline Variabel & Jumlah & Persentasi $(\%)$ \\
\hline \multicolumn{3}{|l|}{ Tekanan darah } \\
\hline \multicolumn{3}{|l|}{ Normal } \\
\hline Sistolik $<120$ & 15 & 25,00 \\
\hline \multicolumn{3}{|l|}{ Diastolik < 80} \\
\hline \multicolumn{3}{|l|}{ Prehipertensi } \\
\hline Sistolik 120-139 & 24 & 40,00 \\
\hline \multicolumn{3}{|l|}{ Diastolik 80-89 } \\
\hline \multicolumn{3}{|l|}{ Hipertensi } \\
\hline \multicolumn{3}{|l|}{$\begin{array}{l}\text { Sistolik } \geq 140 \\
\text { Diastolik }>90\end{array}$} \\
\hline Diastolik > 90 & 21 & 55,00 \\
\hline Total & 60 & 100 \\
\hline Variabel & Jumlah & Persentasi (\%) \\
\hline \multicolumn{3}{|l|}{ Indeks $\quad$ Massa } \\
\hline \multicolumn{3}{|l|}{ Tubuh (kg/m2) } \\
\hline $\begin{array}{l}\text { Obesitas (IMT } \geq \\
30)\end{array}$ & 8 & 13,33 \\
\hline $\begin{array}{l}\text { Overweight (IMT } \\
25-29,9)\end{array}$ & 25 & 41,67 \\
\hline $\begin{array}{l}\text { Normal (IMT 18,5 } \\
-24,9 \text { ) }\end{array}$ & 27 & 45,00 \\
\hline $\begin{array}{l}\text { Underweight (IMT } \\
17-18,4)\end{array}$ & 0 & 0 \\
\hline $\begin{array}{l}\text { Severe wasted } \\
(\text { IMT < 17) }\end{array}$ & 0 & 0 \\
\hline
\end{tabular}

Kesehatan 


\begin{tabular}{|c|c|c|}
\hline \multicolumn{3}{|l|}{$\begin{array}{c}\text { Kadar kolesterol } \\
\text { total }(\mathrm{mg} / \mathrm{dl})\end{array}$} \\
\hline Normal $<200$ & 47 & 78,33 \\
\hline Meningkat $\geq 200$ & 13 & 21,67 \\
\hline \multicolumn{3}{|l|}{$\begin{array}{l}\text { Kadar gula darah } \\
\text { sewaktu (mg/dl) }\end{array}$} \\
\hline Normal $<200$ & 58 & 96,67 \\
\hline Meningkat $\geq 200$ & 2 & 3,33 \\
\hline \multicolumn{3}{|l|}{$\begin{array}{l}\text { Kadar asam urat } \\
(\mathrm{mg} / \mathrm{dl})\end{array}$} \\
\hline $\begin{array}{c}\text { Laki-laki }(3,4-7 \\
\mathrm{mg} / \mathrm{dl})\end{array}$ & & \\
\hline $\begin{array}{c}\text { Perempuan }(2,4-6 \\
\text { mg/dl })\end{array}$ & 40 & 66,67 \\
\hline $\begin{array}{c}\text { Meningkat } \geq 6-7 \\
\mathrm{mg} / \mathrm{dl}\end{array}$ & 20 & 33,33 \\
\hline Total & 60 & 100 \\
\hline
\end{tabular}

Berdasarkan tabel 2 didapatkan kurang dari setengah (40\%) peserta memiliki tekanan darah prehipertensi yang sistolik berkisar 120 $139 \mathrm{mmHg}$ dan diastolik 80 - $89 \mathrm{mmHg}$, kurang dari setengah (45\%) mempunyai IMT normal. Berdasarkan hasil pemeriksaan kesehatan yang dilakukan di GKP Yeruel Cibubur ditemukan lebih dari setengah $(78,33 \%)$ kolesterol normal dan hanya sebagian kecil $(3,33 \%)$ ditemukan kadar gula darah sewaktu yang meningkat sedangkan lebih dari setengah $(66,67 \%)$ kadar asam urat dalam batas normal.

\section{Hasil Kegiatan Pelatihan Pengukuran Tekanan Darah}

Peserta komisi kesehatan yang hadir berjumlah 10 orang dan jemaat umum 22 orang sehingga total peserta 32 orang. Pelatihan dilaksanakan setelah kegiatan pemeriksaan dan edukasi diabetes. Pertama-tama, peserta diminta untuk mengisi kuesioner pre-test yang dibantu oleh tim dari Gereja Kristen Pasundan Yeruel Cibubur dan dilanjutkan dengan pemberian materi pelatihan oleh narasumber dari tim dosen. Seluruh anggota komisi kesehatan tampak antusias mengikuti pelatihan hingga selesai walaupun menyita waktu mereka sampai setengah hari. Peserta pelatihan juga aktif dalam proses pembelajaran. Pada saat praktik, masing-masing peserta didampingi oleh satu fasilitator tim PkM dan mendapat dua kali kesempatan latihan pengukuran tekanan darah. Seluruh peserta awalnya ragu-ragu melakukan tindakan mengingat mereka masih amatir dalam bidang ini, namun menjadi percaya diri setelah berhasil melakukan pengukuran tekanan darah dengan benar. Peralatan pengukuran tekanan darah berfungsi dengan baik sehingga proses pelatihan berlangsung dengan sangat baik. Selesai latihan, para peserta mengerjakan kuesioner post-test. Sebelum kegiatan ditutup, setiap peserta menyampaikan kesan dan pesan yang didapatkan selama bekerja sama dengan tim $\mathrm{PkM}$ dan pendapat mengenai pelatihan di hari tersebut. Semua peserta menyatakan puas dan senang dengan pelaksanaan kegiatan ini. Mereka juga berharap akan diadakan kerja sama berikutnya di waktu yang akan datang supaya peserta bisa terus melatih skill mereka dalam membantu jemaat di Gereja Kristen Pasundan Yeruel Cibubur.

Tabel 3. Distribusi Rata-rata Nilai Pre-post Test

\begin{tabular}{lcc}
\hline \multicolumn{1}{c}{ Variabel } & $\begin{array}{l}\text { Rata-rata } \\
\text { nilai pre-test }\end{array}$ & $\begin{array}{l}\text { Rata-rata } \\
\text { nilai post-test }\end{array}$ \\
\hline $\begin{array}{l}\text { Edukasi Diabetes } \\
\text { Pelatihan }\end{array}$ & 22,89 & 81,21 \\
$\begin{array}{l}\text { Pengukuran } \\
\text { Tekanan Darah }\end{array}$ & 14,44 & 43,33 \\
\hline
\end{tabular}

Dari tabel 3 terlihat bahwa rata-rata (mean) sebelum edukasi diabetes 22,89 dan rata-rata sesudah edukasi adalah 81,21. Demikian juga rata-rata (mean) sebelum pelatihan pengukuan darah meningkat dari 14,44 menjadi 43,33 sesudah pelatihan. Maka dapat disimpulkan bahwa ada peningkatan pengetahuan setelah dan sebelum edukuasi diabetes dan pelatihan pengukuran tekanan darah yang cukup signifikan.

\section{KESIMPULAN}

Kegiatan pengabdian kepada masyarakat berupa Edukasi diabetes, pemeriksaan gula darah dan kolesterol di Gereja Kristen Pasundan Yeruel Cibubur ini berjalan dengan baik dan berhasil bila ditinjau dari kelancaran acara, partisipasi jemaat gereja, dan meningkatnya pengetahuan saat dibandingkan nilai pre test dan post test, walaupun kita tidak bisa memungkiri adanya kekurangan, seperti beberapa peserta yang langsung pulang

Kesehatan

494 
setelah diperiksa, mereka tidak mengikuti edukasi. Dalam kegiatan ini dapat ditarik kesimpulan bahwa:

1. Pencegahan dan pengendalian diabetes perlu dilakukan dengan membangun kesadaran dan peningkatan edukasi kepada masyarakat dengan frekuensi yang berulang kali dan konsisten.

2. Jemaat gereja dengan penyakit kronisdegeneratif seperti hipertensi, diabetes dan lainlain perlu memeriksakan kesehatan secara rutin ke pusat kesehatan terdekat atau memanfaatkan klinik gereja mengingat penyakit tersebut membutuhkan perawatan dan pengobatan yang termonitor secara berkala.

3. Secara umum, pelayanan dapat diberikan dengan baik oleh tim PkM Fakultas Keperawatan dan Ilmu Kesehatan Universitas Pelita Harapan dengan komisi kesehatan Gereja Kristen Pasundan Yeruel Cibubur, walaupun ada beberapa kelemahan.

4. Tindak lanjut dari hasil kegiatan PkM ini adalah dengan melakukan pendampingan kepada mitra yaitu komisi kesehatan Gereja Kristen Pasundan Yeruel Cibubur untuk selalu melakukan sosialisasi dan motivasi kepada jemaat gereja tentang pentingnya melakukan kontrol kesehatan secara teratur, supaya kegiatan ini tidak hanya program hit and run, dan jemaat gereja tidak mendapatkan dampak yang hanya temporer dan terhindar dari penyakit lainnya.

Lewat tulisan ini, juga disarankan beberapa hal; pertama, perlunya kegiatan tindak lanjut program seperti ini di Gereja Kristen Pasundan. Yeruel Cibubur supaya jemaat terus menjaga kondisi kesehatannnya dan komisi kesehatan Gereja Krsiten Pasundan Yeruel Cibubur tetap menjaga skill mereka dalam melakukan kontrol kesehatan kepada jemaat di sana; kedua, kegiatan yang relatif sama bisa dilaksanakan pula di tempat lain oleh tim PKM lainnya, tidak menutup kemungkinan untuk skala yang lebih besar lagi mengingat hal ini telah dilakukan beberapa kali dan bisa belajar dari pengalaman; ketiga, perlu adanya strategi yang tepat bagaimana menjaga para peserta yang sudah melakukan pemeriksaan, untuk tetap setia menunggu mengikuti edukasi kesehatan.

\section{UCAPAN TERIMA KASIH}

Penulis mengucapkan terima kasih kepada Lembaga Penelitian dan Pengabdian Masyarakat (LPPM) Universitas Pelita Harapan atas dukungan dan review yang dilakukan mulai dari pembuatan proposal hingga pembuatan laporan akhir kegiatan. Penulis juga mengucapkan terima kasih sebesarbesarnya pada Universitas Pelita Harapan (UPH) yang telah menyetujui kegiatan terkait dan memberikan bantuan dana untuk kelangsungan kegiatan tersebut. Akhir kata, ucapan terima kasih kami tujukan kepada tim kesehatan Gereja Kristen Pasundan Yeruel Cibubur dan penetua gereja yang mengijinkan dan mendukung pelaksanaan kegiatan edukasi diabetes, pemeriksaan gula darah dan kolesterol di Gereja Kristen Pasundan (GKP) Yeruel Cibubur Serta jemaat atau peserta yang sudah mengikuti kegiatan ini, mulai dari kegiatan pertama dan juga kegitan kedua, serta telah antusias dalam mengikuti kegiatan ini, sehingga kegiatan ini dapat berjalan dengan baik dan juga bermanfaat bagi setiap peserta yang hadir.

\section{REFERENSI}

Badan Penelitian dan Pengembangan Kesehatan Kementerian Kesehatan RI. (2013). Riset Kesehatan Dasar. Diakses dari http://www.depkes.go.id/resources/download/gener al/Hasi1\%20Riskesdas\%202013.pdf

Choudhury, MS J. H., Chowdhury Md T. I., Nayeem A., Jahan W. A., (2015) Modifiable and non-modifiable risk factors of stroke: a review update. diakses dari http://www.banglajol.info/index.php/JNINB/article/ view/22944

Kementerian Kesehatan Republik Indonesia. (2017). Hari Gizi Nasional 2017: Ayo Makan Sayur dan Buah Setiap Hari. Diakses dari http://www.depkes.go.id/article/view/17012600002/ hari-gizi-nasional-2017-ayo-makan-sayur-danbuah-setiap-hari.html

Kementerian Kesehatan Republik Indonesia. (2016). Lansia Sehat: Lansia Aktif, Mandiri dan Produktif. dari 
http://www.depkes.go.id/article/print/16053000001/ lansia-sehat-lansia-aktif-mandiri-dan-produktif.html Mansur, S.N, Wantania, F.E, Surachmanto, E. (2015) Hubungan antara kadar asam urat dengan tekanan darah pada mahasiswa pria obesitas sentral Fakultas Kedokteran Universitas Sam Ratulangi Manado. Diakses dari http://download.portalgaruda.org/article.php?article $=315853 \& \mathrm{val}=1001 \&$ title $=$ HUBUNGAN $\% 20$ ANT ARA\%20KADAR\%20ASAM\%20URAT\%20DEN GAN\%20TEKANAN\%20DARAH\%20PADA\%20 MAHASISWA $\% 20$ PRIA $\% 20$ OBESITAS\%20SEN TRAL\%20FAKULTAS\%20KEDOKTERAN\%20U NIVERSITAS\%20SAM\%20RATULANGI\%20MA NADO

National Stroke Association. (2016). Uncontrollable Risk Factor. Diakses dari http://support.stroke.org/acute_site/risk-factors/

Sari, A. P. (2017). Kolesterol Tinggi. Diakses dari http://www.alodokter.com/kolesteroltinggi
Sihombing, R.M, et.al (2017) Screening dan Edukasi Diabetes Melitus pada Lansia di Posbindu Soka Indah RW 05 Kelurahan Bencongan Indah Tangerang, tidak dipublikasikan

Umami, H. R (2015) Hubungan antara peningkatan kadar asam urat darah dengan kejadian hipertensi di RSUD Sukoharjo. Diakses dari http://eprints.ums.ac.id/39488/17/NASKAH\%20PU BLIKASI.pdf

Gotter, A. Higuera, V. (2018). How Diabetes Affects Women: Symptoms, Risks, and More diakses dari https://www.healthline.com/health/diabetes/sympto ms-in-women

American Diabetes Association. (2019). Diabetes Symtomps. Diakses pada https://www.diabetes.org/diabetes/type-1/symptoms Infodatin. (2014). Situasi dan Analisis Diabetes. Kementerian Kesehatan Republik Indonesia. 